\title{
Aşiret Yapılarında Boşanma Deneyimi: Van Örneği*
}

\author{
Dr. Öğr. Üyesi Aylin Çiçekli \\ Akdeniz Üniversitesi, Sosyal ve Beşeri Bilimler Fakültesi \\ Sosyal Hizmet Bölümü \\ tr_aylinyeldan@hotmail.com
}

\author{
Doç. Dr. Suvat Parin \\ Van Yüzüncü Yıl Üniversitesi, Edebiyat Fakültesi \\ Sosyoloji Bölümü \\ suatparin@hotmail.com
}

Öz

Bu çalışmanın amacı, bir yanda modern çağın kaçınılmaz döngüsü diğer yanda ise gelenek, kültür ve aşiret dokusuyla oluşturduğu toplumsal desene sahip olan Van'da aşiret mensupları arasında gerçekleşen ve bir tabu olarak görülen boşanmaları sosyolojik açıdan irdelemektir. Karakteristik özelliği itibariyle dominant bir eril yapı özelliği sergileyen aşiret yapılarında, modernleşmeyle birlikte, birey ve bireyciliğin etken bir söylem olarak yankı bulduğu günümüzde, gelenekten uzaklaşma, kitle iletişim ve rasyonelleşme hareketleri beraberinde aile ve evlilik kurumunu temelinden sarsmıştır. Türkiye'de 2000'li yıllarla birlikte yükselen bir trend olan boşanma yalnızca modern toplumları değil dirençli bir yapıya sahip olan aşiret örgütlenmelerini de etkilemiştir. Van'daki boşanmış aşiret üyelerini odağına alan bu çalışmada, Van'daki boşanmaları geniş bir açıdan değerlendirmeyi hedeflediğinden 2001-2016 TÜİK boşanma istatistikleri ile birlikte Van'da aşiret üyesi boşanmış 5 kadın, 5 erkek ve boşanma davalarına bakan 5 avukat ile gerçekleştirilen nitel görüşmelerden edinilen geniş veri seti üzerinden çalışıldı. Geleneğin baskın karakteri ile bir tabu olarak görülen boşanmanın, günümüzde Van'da aşiret üyelerinde günlük hayatın pratikleri arasında yer edinmeye başladığı görülmektedir. Boşanmaların gerçekleşmesinde ise kentin sosyolojik dokusu yanında evlilik şekli, ailelerin rolü, aile içi şiddet ve aldatmanın baskın olduğu ortaya çıkmaktadır.

Anahtar Kelimeler: Aşiret, boşanma, aile, geleneksel toplum, modernleşme.

\section{Divorce Experience in Tribal Structures: The Case of Van Province ${ }^{* *}$}

\footnotetext{
Abstract

The aim of this study is to examine the sociological aspects of divorce cases that take place among tribal members in Van - a province adapting to individualist modern age albeit its long-established tribal social setting. The individualism discourse along with the spread of mass communication has brought a distancing from the tradition and, thus, hit hard the family institution characterized by patriarchal tribal structures in the province. To investigate sociological effects of divorce in Van, five male and female divorced tribe members and five divorce lawyers have been qualitatively interviewed. A large data set of

* Bu makale, Doç. Dr. Suvat Parin danışmanlığında tamamlanan “Boşanmalar Üzerine Sosyolojik Bir Araştırma: Van Örneği (2001-2016)" başlıklı doktora tezinden üretilmiştir.

** This article is derived from the PhD study titled "A Sociological Research on Divorces: The Case of Van". 
divorce statistics for the 2001-2016 period provided by TUIK (Turkish Statistical Institute) is also consulted for quantitative insights. Based on the qualitative and quantitative data, it is found that the divorce has started to be seen by the tribe members in Van as a normal practice in life, although it has long been regarded as a taboo before. The dominant causes of divorce in Van are found to be the sociological texture of the city, the marriage style, the role of families, domestic violence and cheating on spouse.

Keywords: Tribe, divorce, family, traditional society, modernization. 


\section{GİRIŞ}

Toplumsal yapının en önemli birimlerinde birisi olan aile, dinamikleri, aile içi rollerin paylaşımı, ekonomik işlevleri gibi sürekli değişen ve dönüşen yapısıyla tarihsel zemin içinde birey, toplum ve devlet üçgeninde tartışlan konuların başında gelmektedir. Evrensel bir aile tanımı yapmanın güçlüğü göz önünde bulundurulduğunda tarihsel süreç içerisinde, zamana, mekâna ve topluma göre değişen ve dönüşen bir yapıya sahip olması en önemli sebep olarak gösterilebilir (Canatan, 2016, s. 97-99). Her toplumun kendisine özgü aile tanımlamasının olması, evrensel aile tanımı yapmayı imkânsız kılmaktadır. Amerikan Aile Araştırma Merkezinin yaptığı tanıma göre aile, iki veya daha fazla bireyin evlilik, birlikte yaşama ya da evlatlık edinme gibi yollarla aynı çatı altında yaşaması olarak açıklanırken (Newman, 1999, s. 6; Cohen, 2005, s. 6); Türk Aile Yapısı Özel İhtisas Komisyonu (1989) tarafından ise kan bağı ya da evlilik yoluyla aynı evde yaşayan bireylerin çeşitli rol ve sorumluluklar etrafında bir araya gelmesi olarak tanımlanmaktadır.

Türkçe 'de evlilik ve ailenin çoğu zaman birbiri yerine kullanılması (Canatan, 2016, s. 56), evlenen kişilerin aynı fiziksel mekânda birlikteliklerini meşrulaştırmalarından kaynaklanmaktadır. Nikah adı verilen 'sözleşme' ile kadın ve erkeğin hukuki anlamda birleştiği kurum olan evlilik (Eyce, 2002, s. 84; Stone, 1979, s. 42-48) insanlık tarihiyle neredeyse eşdeğer bir geçmişe sahiptir. İki yetişkinin meşrulaştırılmış ve onaylanmış cinsel birliktelikleri olarak tanımlanan evlilik (Giddens, 2000, s. 48), eşlerin fiziksel ve duygusal tatminlerini yaşadıkları kutsal bir mabet olan ' $\mathrm{ev}^{\prime}$-de yaşamalarını sağlayan hukuki bir kurumdur.

Son yıllarda hem dünyada hem de Türkiye'de belirgin olarak artan boşanmalarla birlikte, azalan evliliklere eklenen düşen doğurganlık oranları aile tanımının gözden geçirilmesine sebep olmaktadır. Anne, baba ve çocuklardan oluşan aile tanımlarının eksik kaldığı günümüzde, evlilik yaşının ilerlemesi, evlilik oranlarının düşmesi, tek ebeveynli ailelerin artması, nikahsız birlikteliklerin kabullenilmeye başlanması ve hatta aynı cinsiyetten birlikteliklerin gittikçe artması gibi nedenlerle yeni aile tanımlarının yapılması modern dünyanın gereksinimlerinden birisini oluşturmaktadır. Dünya çapında son 150 yılda aileye dair ezberlerin bozulması, özellikle II. Dünya Savaşı'nı takip eden yılların ardından (Poole, 2005, s. 1,2) kendisini göstermiştir. Boşanma sıklığında artan trend, sosyal ve ekonomik bir dayanağı olan evlilik ve aile kurumunun büyük risk altında olduğunu göstermektedir. Hukuki manada evli olan kadın ve erkeğin, duygusal ve fiziksel birlikteliğinin sona ermesiyle başlayıp mahkeme kararı ile kesinleşen süreci anlatan boşanma (Walzack ve Burns, 2004, s. 12-17) sosyal, kültürel, dinsel, ekonomik ve psikolojik boyutları ile toplumu etkilemektedir. Modern hayatın durumsal krizleri arasında sayılan boşanma, ekonomistlere göre kaynaklara erişim noktasında sosyal sermayenin birikimine engel olduğundan sermayenin dağılması olarak tanımlanırken (Becker, 1981; Fuchs, 1983); sosyolog ve gelişim psikologlarına göre ise birlikte yaşamayan ebeveynlerin toplumsal değişim ve iş birliğine engel olarak çocuklar üzerinde kurulacak olan oto kontrolün azalması, dolayısıyla da sosyalizasyon sürecinde yaşanacak eksiklik olarak nitelendirilmektedir (Furstenber ve Kiernan, 2001; Coleman, 1988; Furstenberg, 1998).

Sanayileşme öncesi dönemde, hane halkı ve akrabalar tarafından ekonomik manada desteklenen bir birim olan aile (Gökçe, 1996: 156), sanayileşmeyle birlikte ev dışında ücretli çalışmanın da etkisiyle kamusal alanla birlikte anılmaya başlamıştır (Laslett, 1972). Avrupa'da başlayıp ardından dünyaya yayılan modernleşme, değişen toplumsal eğilimlerin 
de en büyük müsebbibi olarak görülmekle birlikte (Giddens, 2014a), sadece toplumsal yaşam tarzında dönüşümü değil özel bir alan olan ailede de 'mahremiyetin dönüşümü'nü sağlamaktadır (Giddens, 2014b). Modernleşmeyle beraber aile hayatının mahremiyetini ifade eden kadının ev dışında ücretli olarak çalışmaya başlaması da, toplumsal cinsiyet rolleri içinde otorite sahibi erkeğin tahakküm politikalarını yerinden sarsmaya başlamıştır. Bir ailenin geçimini sağlamak, erkek için en önemli tahakküm yollarından birisi olmakla birlikte toplum tarafından saygın bir erkeklik inşa etmenin de ilk prensiplerinden birisini oluşturmaktadır (Sancar, 2013). Erkekliğin kazanılıp, kadınlığın atfedildiği toplumda (Kandiyoti, 1987), erkeklerin erilliğini ispat etme araçlarından biri olan evin ekmek kazananı (breadwinner) rolünün (Kimmel, 2002) kadına geçtiği durumlarda toplum tarafından erkek, eşinin ihtiyaçlarını karşılayamamakla yargılanırdı (Cherlin, 1992).

1970'lerde Avrupa, Amerika ve diğer gelişmiş dünya ülkelerinde en yüksek seviyesine ulaşan boşanmalar, 2015 yılı Avrupa Birliği İstatistik Kurumu verilerine göre Avrupa Birliği (AB) üye ülkelerin ortalama boşanma oranı gerçekleşen evliliklerin \% 40 '1 olarak tespit edilmiştir. Amerika Birleşik Devletleri'nde (ABD) ise durum farklı olmamakla birlikte her dört evlilikten ikisinin bittiği (Riessman, 1990, s. 4) ve hatta tarihçi Lawrence Stone'a (1989, s. 12) göre ise boşanmada yukarıya doğru yaşanan ivme devam ettiği takdirde Amerika ve İngiltere' de her 3 evlilikten birisinin sonlanacağını belirtmiştir.

Türkiye açısından bakıldığında ise 1950'lerde ani artış gösteren kentleşmeyle birlikte geleneksel geniş aileden modern çekirdek aileye doğru yaşanan değişim (Dikeçligil, 1995) mahremiyet, anne-baba-çocuk ilişkileri ve toplumsal cinsiyet tartışmalarını da tetikleyerek (Kümbetoğlu, 1997, s. 112-116) doyumsuz evlilik ilişkilerini beraberinde getirmiştir. 2001 yılı itibariyle Türkiye'de her 100 evlilikten 16,90'1 boşanma ile sonuçlanıyorken, yıllar içinde yaşanan dalgalanmalarla birlikte 2016 yılındaki bu oranın \%21,22'ye ulaştı̆̆ görülmektedir (TÜIK, 2016).

Her evlenme ve boşanma olayının yaşandığı coğrafyanın sosyolojik özelliklerini yansıttığı gerçeğiyle, toplumsal doku, boşanma örüntülerini anlamlandırmada üzerinde durulması gereken önemli bir sosyolojik realite olarak görülebilir. Sosyo-ekonomik göstergeler göz önünde bulundurulduğunda, geleneksel toplum kodlarının daha baskın olduğu Van'da 2001-2016 yılları arasında boşanma oranlarının artan bir trend izlediği tespit edilmektedir. 'Gelinlikle girer, kefenle çıkarsın' toplumsal kuralının boşanmayı 'ayıp' ve 'kabul edilemez' gördüğü toplumsal dokuda, boşanmaların artışı sosyolojik manada önem arz etmektedir. Bu çalışmanın odağında geleneksel toplum kodlarının hâkim olduğu Van'da aşiret gerçekliğine rağmen boşanma olaylarının ardında hangi dinamikler etkilidir? sorusu yer almaktadır. Sorunun yanıtlanmasında istatistiki verilerden oluşan ikincil veriler ile aşiret üyesi olup boşanmış çiftlerin konuya yaklaşımlarını irdeleyen birincil nitel veriler kullanılmıştır.

\section{Gelenekselden Moderne Ailede Yaşanan Dönüşüm}

Sanayi devrimiyle birlikte, kapitalist ekonominin itici gücü, insanları kırdan kente göçe zorlarken yaşanan kentleşme/kentlileşme ile birlikte de toplumsal boyutta değişim ve dönüşümleri beraberinde getirmiştir. Toplulukların ve akrabalık ilişkilerinin yerini alan birey ve bireye dair birçok mevzu günlük pratiklerin dönüşümüne sebep olmuştur (Yıldırım, 2016, s. 122-123). Kırdan kente yaşanan göç ile birlikte terk edilen geleneksel tarım ailesi yerini hızlıca topluma egemen olan modern aile tipine kaptırmıştır (Poster, 1978, s. 610). Aileyi bir arada tutan üretim ilişkilerinin yerini alan sanayileşme ile aile önce zayıflamış 
ardından da postmodern dünyanın bireysel çıkarlarının üzerine eklenmesi ile boşanmalar kaçınılmaz olarak artmıştır (Cheal, 1999, s. 10).

Zaman ve mekana göre değişen insan davranışları, dönemin içinde bulunduğu şartlara göre uyum sağlayarak toplumsal kabulleri oluşturmaktadır. Dolayısıyla, geleneksel, üreten tarım toplumlarından tüketen modern topluma geçişte duygusal ve romantik ilişkilerin öne geçtiği (Bauman, 2001; 2009; 2017), simule sosyal ortamların revaçta olduğu (Baudrillard, 2003), doğrunun, yanlışın, iyinin, kötünün muğlaklaştırılıp, robotik hayatların yaşandığı (Ritzer, 2000) gibi bireysel arzuların ön planda yargılanmaksızın kabul gördüğü modern karakterler ortaya çıkmıştır. Ekonomi, kültür, siyaset ve sosyal dönüşümlerin etkisiyle yeniden şekillenen toplumda, bu değişimin ilk hissedildiği yer de aile kurumudur.

Mahrem olan ailenin kitle iletişim araçları ile kamusal kimliğe dönüşümü (Giddens, 2014b) modernleşme adı altına ideal bir yapı olarak sunulmaktadır (Yıldırım, 2016, s. 124; Can, 2014, s. 61). Gerek dünya gerek Türkiye'de modernleşme sonucu artan bireyselleşme, teknolojinin geleneksel yapı üzerindeki olumsuz etkisi, ahlaki çöküş, tüketimin bir alışkanlık haline gelmesi, tahammülsüzlük ve doyumsuzluk gibi etkenler ilişkileri metalaştırarak boşanmaların artan bir trende sahip olmasına sebep olmuştur (Poole, 2005, s. 13-27; Stacey, 1996, s. 20-32; Zaretsky, 1976). Ayrıca toplumsal cinsiyet söylemlerinin sebep olduğu kadının statüsünün olumlu anlamda değişmesi de çiftlerin özgürleşmesini sağlamıştır. Kentleşme ile kadının sosyalleşmesi, kamusal alana katılımı, artan eğitim seviyesi de eşler arasındaki çatışmaları kamçlamaktadır (Sevim, Güldeste ve Öner, 2016, s. 300; Sancar, 2013). En önemlisi de bireyselleşmenin etkisi ile denetim mekanizmaları ve otoriteleri hiçe sayan bireyin din, gelenek ve toplumsal sözleşmeleri bertaraf etmesi, kırılgan, akışkan ve kısa ömürlü dahası; muadiline her zaman ulaşabileceği ilişki tipini doğurmuştur (Bauman, 2017). Postmodern toplumda yaşanan aşırı esneklik sonucunda her şeyi arzulayan insan; kendisine ayak bağı olacak bağlılık ve bağımlılıklardan uzak durmayı yaşam felsefesi haline getirmiştir. Bauman'ın (2017, s. 164) dediği gibi 'akşamleyin viagra, sabaha doğum kontrol hapı...', 'ölüm bizi ayırana kadar' yemininin yerini 'ölene dek seni çekemem' söylemine bırakmıştır. Beck ve Beck, "Aşkın Normal Kaosu”nda (2012, s. 11-16) geleneksel ailenin ortadan kalkarak modern sonrası dönemine işaret ederek bireyin, aile, aşk, iş gibi beraberce yürütmek yerine birbirlerine tercih ettiği dönemi tecrübe ettiğimizi vurgulamaktadır. $\mathrm{Bu}$ noktada ailenin çözüldüğü ya da ortadan kalkacağı inancının yerini ailenin format değiştirerek nikahsız birliktelikler, tek ebeveynli aileler, eşcinsel evlilikler gibi farklı tarzda aileler almaktadır (Beck ve Beck, 2012, s. 36-37; Albers, 1999, s. 367).

\section{Aşiret ve Aile}

Geleneksel yapı örneklerinden olan aşiret oluşumlarında, bireyin değil aile kavramının önemli olması ve aile içindeki kontrol mekanizmasının ailenin yaşça en büyügünün elinde bulunması (Eyce, 2002, s. 28-230) ile kapalı toplum karakterine sahip geniş aile yapısı hakimdir. Yüzlerce yıldır varlıklarını bu sayede koruyan ve feodal yapıya örnek gösterilebilecek aşiretler (Parin, 2019) geleneksel aile yapısını korumaktadırlar. Dolayısıyla süregelen aşiret ilişkileri Doğu ve Güney Doğu Anadolu bölgelerini Türkiye'den farklı kılan özelliklere ev sahipliği yapmaktadır (Türkdoğan, 2013, s. 22-23). Toplumsal örgütlenme modeli olarak kabul edilen aşiret yapılanmaları (Beşikçi, 1992, s. 101), aşiret reisinin hegemonik varlığıyla birçok fonksiyonu yerine getirirken (Özer, 1993, s. 104) kan ve akrabalık ilişkileri ile 'biz' bilincini yaşadıkları toplumda hakim kılmışlardır. Türkiye nüfusunun \%5'inin aşiret oluşumlarından meydana geldiği gerçeğiyle (Türkdoğan, 2013, s. 
45) aile ve akrabalık ilişkileri varlıklarını devam ettirmeleri noktasında önem arz etmektedir. Ataerkil aile modeli ortaya koyan bu tarz Kürt oluşumları, erkek egemen gündelik rutinlerle 'kadınların erkekler tarafindan ezildiğgi ya da ikinci sını görüldü̈̆̈̈' bir toplum modeli sergilemektedir. Aşiret reisinin erkek olması, erkek çocuğun kız çocuktan değerli görülmesi, mirasta erkeğin söz hakkı, akrabalığın erkek soyundan ilerlemesi gibi daha da genişletilebilecek birçok sosyal performanslarla erkek otoritesi pekiştirilmektedir. Dişil bir mekan olarak görülen hanede, erkeğin kadın ile aynı sofraya oturmaması, ayrı odaya sahip olması (Yalçın-Heckmann, 2016, s. 226-227) Kürtlerde erkeklik imajını daha da kuvvetlendirmiş ve bu çerçevede toplumsal cinsiyet rolleri kesin çizgilerle belirlenmiştir. Bazı araştırmalar tam tersini iddia etmekle birlikte özellikle göçebe aşiret kadınının hane dışında çalışması ve ev içinde söz hakkının olması kadının çalışkanlığı olarak açıklanmaktadır (Öztürk, 2004, s. 175; Beşikçi, 1992, s. 32-33). Özellikle kentleşmeyle birlikte eve kapanan aşiret kadını erimeye başlamış, modernleşme hareketleri en büyük çıkmazları olmuştur. Modernleşmenin bir sonucu olan kentleşme, beraberinde 'güven' sorununu getirerek (Giddens, 2004, s. 35-40) özellikle aşiret kadınını kentte dört duvar arasına hapsetmiştir (Uluç ve Karasu, 2015).

Aşiret ve akrabalık ilişkilerinin evlilik kurumu üzerinden devam ettiği gerçeğiyle, aşiretin ideolojisi, hiyerarşisi, kuralları, ilişkileri evlilik süreci ile birebir bağlantılıdır. Evrensel bir oluşum olan evlilik, aşiret yapılanmalarında çeşitli ilişki ve değer bağlarını da yakından ilgilendirmektedir (Yıldırım, 2004, s. 106-108). Aşiret yapılanmalarında özellikle görülen akraba evlilikleri, berdel, çocuk yaşta evlilik gibi mevzular ile ailenin kontrolü sağlanırken (Yalçın-Heckmann, 2016, s. 290-332) ekonomik ve siyasi gücü olanların çocuk gelinlerle yaptıkları evlilikleri ve çok eşli evlilikleri (Yıldırım, 2004, s. 85-109) ise o kişinin aşiret içindeki prestijini göstermektedir. Aşiretlerde en çok karşılaşılan evlilik örüntüsü olan amca kızı/amca oğlu ilişki biçiminde, kız üzerinde izdivaç hakkına sahip olan ilk kişi amca oğludur; o istemediği taktirde kız başkası ile evlendirilebilir (Öztürk, 2004, s. 179). Gerçekleşen akraba evliliği ile mülkiyet dolaşımı da yine aile içinde kalmaktadır.

Aşiretlerde görülen bir diğer evlilik örüntüsü ise berdel usulü gerçekleşen evliliklerdir. Kız değiştirme olarak da adlandırılan bu yöntem ile aynı aileden iki çift karşılıklı kız alıp vererek takas yöntemi ile evlenirler. Eş zamanlı gerçekleşen bu evlilikte, ailelerde yaşanan sorunlar da eş zamanlı olarak diğer aileye yansıtılmaktadır (Yıldırım, 2004, s. 109). Ayrıca başlık parası yerine kullanılan bu yöntem (Özer, 2003, s. 100) özellikle dar gelirli aileler arasında hala varlığını devam ettirmektedir. Tartışmalara konu olan diğer evlilik örüntüsü levirat ise ölen erkeğin dul kalan karısının gerek miras payını korumak gerekse de çocuklarının mağdur olmaması adına kayın biraderi ile evlendirilmesidir (Stirling, 1965, s. 198; Yalçın-Heckmann, 2016, s. 310-311).

Aşiret içinde katı olarak gerçekleştirilen günlük yaşam pratiklerine bakıldığında, sosyal kontrol mekanizmalarını sıkı denetimi ile varlığını sürdüren geleneksel aile oluşumlarında ailenin çözülmesi mevzusu kulağa olası gelmemektedir. Berdel evlilik ile diğer evlenen çiftin de mutluluğunun garantisi verilirken gerçekleşen akraba evlilikleri ile de bireysel çıarlardan ziyade önem arz eden aile çıkarları boşanmayı neredeyse olanaksız kılmaktadır. Aşiretlerde mahrem alanı olmayan kadın ve erkeğin kendi içlerinde yaşadıkları herhangi bir olumsuzluk anında boşanma kararı alma zorluğu ya da imkansızlı̆̆ı böyle bir sürecin gerçekleşmesinin dillendirilmesini dahi olanaksızlaştırmaktadır. 


\section{Yöntem ve Gerekçeler}

Geleneksel ailede 'kolun kırılıp yenin içinde kaldığı' dönemden mahremiyetin kamusallaştığı döneme hızlı bir dönüşüm geçiren Van'da geleneksel ve moderni aynı anda bünyesinde barındıran sosyolojik dokuda aile, evlilik ve boşanma olaylarını incelemek önem arz etmektedir. Sosyal gelişmişlik indeksinde son sıralarda yer alan ve geleneksel toplumsal yapıya sahip olan Van'da boşanma Anadolu'nun diğer kentleri gibi 2000'li yılların ardından kendisini göstermeye başlamıştır. Dolayısıyla hem sosyo-ekonomik açıdan geri sıralarda yer alıp hem de toplumsal dokusunda aşiret yapısını barındıran Van'da boşanma konusu merak uyandırmaktadır. Ayrıca boşanmanın Türkiye'de hissedilmeye başlandığı 2000'li yıl ile birlikte çalışmaya başlanan tarih olan 2016 tüm çalışmanın evrenini oluşturmaktadır.

Araştırmanın ana problemi, aşiret yapısı itibariyle geleneksel değerlerin hakim olduğu Van'da 2001-2016 yılları arasında boşanma oranlarında yaşanan \%319'luk artışın ardında hangi toplumsal faktörlerin yer aldığını incelemektir. Ayrıca aşiret üyesi boşanmış kadın ve erkeklerin evlilik, aile ve boşanmaya dair tutum ve davranışlarının nasıl bir sosyolojik yapıya işaret ettiği ise alt problemi oluşturmaktadır.

Araştırmaya dair belirlenen problemler neticesinde çalışmada hem nitel hem de nicel araştırma verileri birlikte kullanılmıştır. Nicel veriler 2001-2016 yılları arasında TÜiK kayıtlarından, nitel veriler ise Van kent merkezinde aşiret üyesi boşanmış 5 kadın, 5 erkek katılımcı ile Van'da boşanma davalarına bakan 5 boşanma avukatıyla yapılan görüşmelerden elde edilmiştir. Van kent merkezinde 15 kişi ile gerçekleştirilen yarı yapılandırılmış mülakatlar katılımcının kendisini rahat hissettiği ev, kafe, iş yeri gibi mekanlarda gerçekleştirilirken görüşmeler ses kayıt cihazı ile kaydedilmiş ve ardından deşifre edilmiştir. Yüz yüze görüşmeyi reddeden katılımcılar ise yazılı olarak cevapladıkları mülakat formunu e-mail yoluyla ulaştırmışlardır. Van kent merkezinde gerçekleştirilen araştırmada katılımcılara Aile Destek Merkezleri (ADEM) ve avukatların yönlendirmeleri sonucunda ulaşılmıştır.

Van kent merkezinde aşiret üyesi hukuki düzlemde boşanmış 5 kadın, 5 erkek ve 5 boşanma avukatı ile gerçekleştirilen yarı yapılandırılmış görüşmeler analiz edilerek istatistiklerin kapalı bıraktığı aşiret üyelerinin boşanmaya dair tutumları geniş bir bakış açısıyla değerlendirilmektedir. Deşifre edilen yarı yapılandırılmış görüşmelerde, katılımcıların gizlilik ilkesi gereği isimleri gizli tutularak kadın katılımcılar K1, K2, K3, K4, K5; erkek katılımcılar E1, E2, E3, E4, E5; boşanma davasına bakan kadın avukatlar KA1, KA2, KA3 ve erkek avukatlar EA4, EA5 olarak kodlanmaktadır. Elde edilen veriler 'Aşiretlerde Evlilik Kurgusu', 'Aşiretlerde Evlilik Sürecinde Yönlendirme Ailesi' ${ }^{1}$ Rolü', 'Aşiretlerde Boşanma Nedenleri', 'Aşiretlerde Yönlendirme Ailelerinin Boşanmaya Tepkisi' ve 'Boşanan Kişilere Toplumsal Baskılar' alt başlıkları ile boşanmış kişilerin hikayeleri irdelenerek analiz edilecektir. Analizlere geçmeden önce katılımcıların ve boşandıkları eşlerinin eğitim, yaş, meslek, akrabalık derecesi, evlilik şekli ve evli kalınan süre verilerek sosyolojik analizlerin daha anlamlı yapılması amaçlanmaktadır (Tablo 1).

1 Yönlendirme ailesi kavramı ile yeni aile kurmuş gelin ve damadın, evlenmeden önce sahip oldukları aile tanımlanmaktadır.

SEFAD, 2020; (43): 345-368 
Tablo 1. Katılımcıları Tanıtıcı Veriler

\begin{tabular}{|c|c|c|c|c|c|c|c|c|c|}
\hline & & Yaş & Eğitim & $\begin{array}{c}\text { Boşandığ } 1 \\
\text { Eşinin } \\
\text { Eğitim } \\
\text { Durumu }\end{array}$ & Meslek & $\begin{array}{l}\text { Boşand1 } \\
\text { ğ Eşinin }_{\text {Mesleği }}\end{array}$ & $\begin{array}{c}\text { Akrabalık } \\
\text { Derecesi }\end{array}$ & Evlilik Şekli & $\begin{array}{l}\text { Evlilik } \\
\text { Süresi }\end{array}$ \\
\hline $\begin{array}{l}\text { Kadın } \\
\text { Katılımcı } 1\end{array}$ & K1 & 32 & Lise & Lise & İş-kur & Galerici & $\begin{array}{c}\text { Uzaktan } \\
\text { akraba }\end{array}$ & Severek & 5 \\
\hline $\begin{array}{l}\text { Kadın } \\
\text { Katılımcı } 2\end{array}$ & K2 & 40 & Yok & Yok & İşsiz & $\begin{array}{c}\text { Tir } \\
\text { Şoförü }\end{array}$ & - & $\begin{array}{c}\text { Görücü } \\
\text { usulü }\end{array}$ & 25 \\
\hline $\begin{array}{l}\text { Kadın } \\
\text { Katılımcı } 3\end{array}$ & K3 & 25 & Lise & Lise & Tezgahtar & İ̧̇siz & - & Severek & 5 \\
\hline $\begin{array}{l}\text { Kadın } \\
\text { Katılımcı } 4\end{array}$ & K4 & 33 & Lisans & Lisans & Memur & Yönetici & $\begin{array}{c}\text { Uzaktan } \\
\text { akraba }\end{array}$ & Severek & 8 \\
\hline $\begin{array}{l}\text { Kadın } \\
\text { Katılımcı } 5\end{array}$ & K5 & 47 & İlkokul & Ortaokul & İ̀ssiz & İंşsiz & $\begin{array}{c}\text { Amca } \\
\text { çocukları }\end{array}$ & $\begin{array}{c}\text { Görücü } \\
\text { usulü }\end{array}$ & 16 \\
\hline $\begin{array}{l}\text { Erkek } \\
\text { Katılımcı } 1 \\
\end{array}$ & E1 & 35 & İlkokul & Yok & İşsiz & İşsiz & - & Severek & 11 \\
\hline $\begin{array}{l}\text { Erkek } \\
\text { Kat1lımcı } 2 \\
\end{array}$ & E2 & 38 & Lise & İlkokul & $\begin{array}{c}\text { Oto } \\
\text { tamircisi }\end{array}$ & İşsiz & $\begin{array}{c}\text { Uzaktan } \\
\text { akraba }\end{array}$ & Severek & 1 \\
\hline $\begin{array}{l}\text { Erkek } \\
\text { Katılımc1 } 3 \\
\end{array}$ & E3 & 56 & Lise & Lise & Serbest & Serbest & - & Severek & 3 \\
\hline $\begin{array}{l}\text { Erkek } \\
\text { Katılımc1 } 4\end{array}$ & $\mathrm{E} 4$ & 48 & Lisans & İlkokul & Mühendis & İंşsiz & $\begin{array}{c}\text { Teyze } \\
\text { çocukları }\end{array}$ & $\begin{array}{c}\text { Görücü } \\
\text { usulü }\end{array}$ & 18 \\
\hline $\begin{array}{l}\text { Erkek } \\
\text { Katılımcı } 5 \\
\end{array}$ & E5 & 42 & $\begin{array}{c}\text { ÖnLisa } \\
\text { ns }\end{array}$ & Ortaokul & Tekniker & İşsiz & - & $\begin{array}{c}\text { Severek+Gör } \\
\text { ücü }\end{array}$ & 10 \\
\hline
\end{tabular}

TÜIK'ten edinilen 2001-2016 yılları arasına ait ham ikincil veriler Duncan Multiple Range Test ile 3 ayrı yıl kategorisine göre 2001-2006, 2007-2011 ve 2012-2016 incelenerek ortalamalar üzerinden yıllar ve değişkenler arasındaki farklılıklar analiz edilmiştir. Analizler neticesinde anlamlı farklılıklar ortaya çıkmıştır $(p<0.01)$. Çalışmanın haritalandırma kısmında ise Coğrafi Bilgi Sistemleri (CBS) 'Geographical Information System (GIS)' programı uygulanarak TÜiK'ten elde edilen sayısal veriler somut ve anlaşılır hale getirilmiştir. 2001'den 2016'ya değişimi göstermek adına Türkiye' de bölge bazında boşanma sayıları, hızları ve genel nüfus içindeki oranları verilirken; ayrıca illerin ayrıntılı olarak boşanma hızları da haritalandırılmıştır.

\section{Bulgular}

Van'ı evlilik ve boşanma istatistikleri üzerinden tartışmadan önce, kente dair sosyoekonomik gelişmeler ile aşiret oluşumlarına değinmek gerekmektedir. Devlet Planlama Teşkilatı (DPT), Kalkınma Bakanlığı, Devlet İstatistik Enstitüsü (DİE) verileri ile gerçekleştirilen etütlerle birçok medeniyete ev sahipliği yapmış olan Van, 1980 yılına dek problemlerle anılan bir kent olması sebebiyle gelişmişlik endeksinde geri sıralarda yer almıştır. 1980 yılında kentleşme ve sanayileşme alanında atak yaparak tarihindeki en yüksek seviyeye ulaşarak, ardından terör ve şiddet olaylarının olumsuz etkileri ile günümüze dek düşen bir trend izlemektedir (Parin ve Demirci, 2016, s. 32). (Tablo 2) 
Tablo 2. Van'ın Sosyo-Ekonomik Gelişmişlik Endeksi ve İl Sıralaması (1996-2011)

\begin{tabular}{|c|c|c|}
\hline Y11 & $\begin{array}{c}\text { Gelişmişlik } \\
\text { Endeksi }\end{array}$ & İ Sıralaması \\
\hline 1996 & -0.95546 & 71 (76 il içinde) \\
\hline 2000 & -1.09297 & 75 (81 il içinde) \\
\hline 2003 & -1.09297 & 75 (81 il içinde) \\
\hline 2010 & -5.8239 & 76 (81 il içinde) \\
\hline 2011 & -1.3783 & 75 (81 il içinde) \\
\hline
\end{tabular}

Kaynak: Bölgesel Gelişme ve Yapısal Uyum Genel Müdürlüğü, 2011

Ekonomi, ulaşım, eğitim, tarım, sanayi, turizm gibi parametreler üzerinden değerlendirildiğinde geri sıralarda olan Van'da bugün hala varlığını sürdüren aşiret oluşumları siyasi, toplumsal ve kültürel hayat üzerinde yadsınamayacak etkiye sahiptir. Günümüze direkt aşiret ilişkisi olarak yansımasa da birçok kültürel ve toplumsal farklılıklar 'alışkanlık' olarak var olagelen ritüellerini devam ettirmektedirler. Parin tarafından 2018 yılında Van kent merkezinde gerçekleştirilen araştırmaya göre 50'nin üzerinde aşiret yapılanmasının varlı̆̆ı sonuçlara yansımıştır (Parin, 2018). Dahası kent yaşamında sosyal dayanışma gerektiren düğün, taziye ve doğum gibi ritüellerde maddi ve manevi destek yönünden aşiretlerin etkisi bulgularla kanıtlanırken bireysel problemlerde aşiret aidiyetliğinin bertaraf edildiği dikkat çekmektedir.

Türkiye'de boşanmalar: Van; sahip olduğu geleneksel değerlerin etkisiyle 2000'li yıllara dek gerek doğurganlık hızını gerek evlenme ve boşanma oranlarını korumuştur. Devlet İstatistik Enstitüsü (2000) verilerine göre de hane halkı sayısı bakımından Türkiye ortalamasının üzerinde seyrederek, \%70 oranında hane halkı sayısı 5 kişi ve üzeri olarak hesaplanmıştır. PKK terör örgütü ve devlet arasında 1987 yılında başlayan şiddetli çatışmalar sonucunda, özellikle 1990 'lı yıllarda kentleşme oranı ani bir yükselişe geçmiş ve Van'da \%82,2 oranında kent nüfusunda artış istatistiklere yansımıştır (Yıldız ve Alaeddinoğlu, 2016, s. 224-227).

2016 yılında kaba evlenme hızı açısından Türkiye'de 7. olan Van, 2001-2007 yılları arasında genel olarak yükselen bir trend izlemekle birlikte 2008 yılının ardından düzenli bir düşüşe geçmiştir. Van'da kaba evlenme hızı 2001'den 2016'ya dek \%o1,38 oranında düşüş gösterirken bu istatistikler Türkiye geneli için kaba evlenme hızında düşüşü \%o0,85 olarak göstermektedir (Tablo 3). İlk evlenme yaşı açısından değerlendirildiğinde ise, Türkiye'de erkekler için ortalama 27,1, kadınlar için ise 22,1 olarak hesaplanmıştır (TÜIK, 2016). Van Kadın Araştırmalar Derneği'nin (VAKAD) 2006 yılında Van kent merkezinde yaptığ1 araştırma ise kadınların ortalama ilk evlenme yaşını 17 olarak tespit etmiştir. Ayrıca kadınların \%33,4'ü ise 11-17 yaş arasında evlendiklerini beyan etmişlerdir. İmam nikahlı evliliklerin fazlalığı ile resmi istatistiklere yansımayan bu rakamlar çocuk gelin sayısının fazlalığına da işaret etmektedir. 
Tablo 3. Türkiye ve Van'da Kaba Evlenme ve Boşanma Oranları (2001-2016)

\begin{tabular}{|c|c|c|c|c|}
\hline & $\begin{array}{c}\text { Türkiye Kaba } \\
\text { Evlenme Hı1 }\end{array}$ & $\begin{array}{c}\text { Van Kaba } \\
\text { EvlenmeHız1 }\end{array}$ & $\begin{array}{c}\text { Türkiye Kaba } \\
\text { Boşanma Hız1 }\end{array}$ & $\begin{array}{c}\text { Van Kaba } \\
\text { Boşanma Hız1 }\end{array}$ \\
\hline 2001 & 8,35 & 9,97 & 1,41 & 0,09 \\
\hline 2002 & 7,73 & 7,44 & 1,44 & 0,11 \\
\hline 2003 & 8,47 & 10,57 & 1,39 & 0,13 \\
\hline 2004 & 9,10 & 10,45 & 1,35 & 0,12 \\
\hline 2005 & 9,37 & 10,54 & 1,40 & 0,12 \\
\hline 2006 & 9,18 & 10 & 1,35 & 0,17 \\
\hline 2007 & 9,10 & 10,26 & 1,34 & 0,17 \\
\hline 2008 & 9,04 & 9,97 & 1,40 & 0,16 \\
\hline 2009 & 8,21 & 9,34 & 1,58 & 0,24 \\
\hline 2010 & 7,97 & 8,91 & 1,62 & 0,26 \\
\hline 2011 & 7,99 & 8,76 & 1,62 & 0,24 \\
\hline 2012 & 8,03 & 9,08 & 1,64 & 0,20 \\
\hline 2013 & 7,88 & 9,54 & 1,65 & 0,27 \\
\hline 2014 & 7,77 & 9,57 & 1,70 & 0,31 \\
\hline 2015 & 7,71 & 9,05 & 1,69 & 0,31 \\
\hline 2016 & 7,50 & 8,59 & 1,59 & 0,30 \\
\hline
\end{tabular}

Kaynak: TÜİK Evlenme ve Boşanma İstatistikleri (2001-2016)

Türkiye'nin her bölgesi ve hatta her kentinde yaşanan farklı boşanma çıtılarının olması sonucunda, kentin ve yörenin içinde barındırdığı kültürel yapı, yerel dinamikler ve sosyo-ekonomik gelişmişlik endeksi gibi kriterlerin etkili olduğu söylenebilir (Harita 1-2-34). Sanayileşmeyle birlikte artan bireyselleşme toplumsal dokuyu hakimiyetine geçirirken, tüm toplumların da ayn süreçten aynı zaman diliminde geçtiğini söylemek doğru olmaz. Bir yanda modern toplum pratikleri günlük hayatı kıskacına almışken diğer tarafta modernizme meydan okurcasına feodal yapıların varlığını sürdürmesi de beraberinde bölgesel ve yöresel farklılıkları meydana getirmektedir.

Boşanmaların Türkiye'de bölgeler arasında ve iller arasında dağılımına bakıldığında 2001-2016 yılları arasında Marmara Bölgesi \%35 ile en yüksek paya sahipken, ardından ise sırasıyla \%18 ile Ege Bölgesi, İç Anadolu Bölgesi, Akdeniz Bölgesi, Karadeniz Bölgesi, Güney Doğu Anadolu Bölgesi ve Doğu Anadolu Bölgesi gelmektedir (Harita 1-2). İstatistiklere yansıyan rakamlar ile alan araştırma sonuçları göstermektedir ki Doğu Anadolu Bölgesi Türkiye'nin en düşük boşanma hızına sahip olan bölgesidir (Harita 1-2). 
Harita 1. Bölgelere Göre Boşanma Oranları (2001)

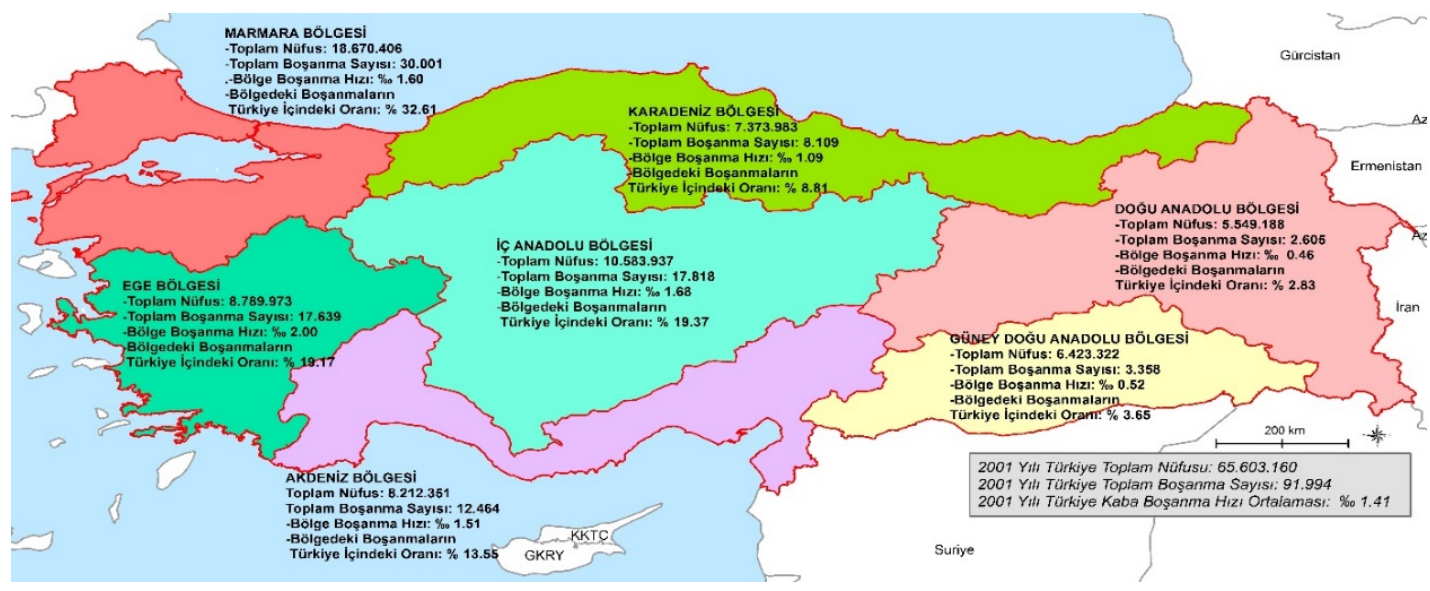

Kaynak: TÜİK Boşanma İstatistikleri (2001)

Harita 2. Bölgelere Göre Boşanma Oranları (2016)

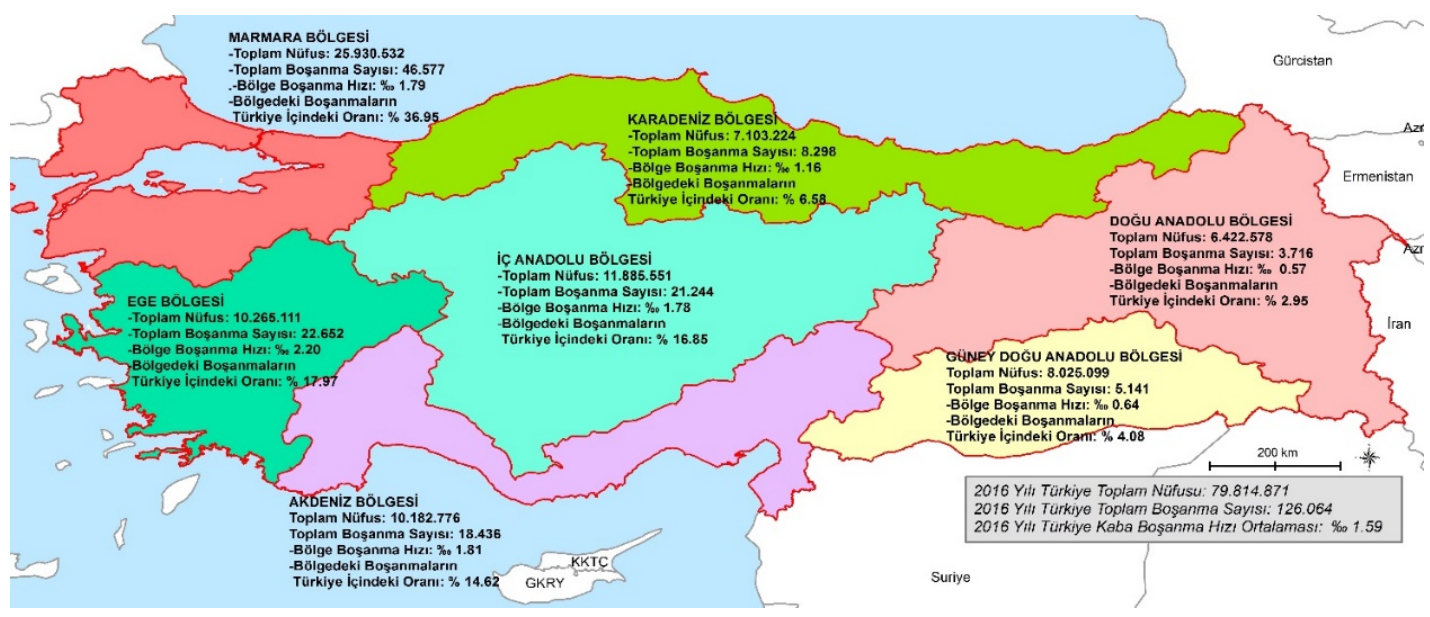

Kaynak: TÜIKK Boşanma İstatistikleri (2016)

Van'da boşanma istatistikleri (2001-2016): Araştırmaya konu olan 2001-2016 yılları arasında genel olarak Van'da kaba boşanma hızı \%o0,09'dan \%o0,30'a yükselmiş (Harita 3-4), boşanma sayısı ise 2001 yılında 78 iken 2016 yılı itibariyle resmi kayıtlara 327 olarak yansımıştır. Bu da gösteriyor ki Van'da boşanma sayısı 2001'den 2016'ya dek \%319 oranında artmıştır. Türkiye geneline bakıldığında 2001 ve 2009 yıllarında yaşanan ekonomik krizler evlenme ve boşanma oranlarını ciddi oranda etkileyerek evliliklerin azalıp, boşanmaların artmasına etki eden önemli bir faktör olarak değerlendirilirken; Van'da ise 23 Ekim 2011 yılında gerçekleşen, maddi ve manevi kayıplara sebep olan depremin etkisiyle evlenme ve boşanma sayıları yöresel bağlamda etkilenmiştir. Genel olarak Türkiye'de 2016 yılında her 1000 kişiden 7,50'si evleniyorken, evlenenlerin 1,59'u evliliğini sonlandırmaktadır. Van'da ise her 1000 kişiden 8,59'u evleniyorken, 0,30'u boşanmaktadır. 
Harita 3. İllere Göre Boşanma Hızı (2001)

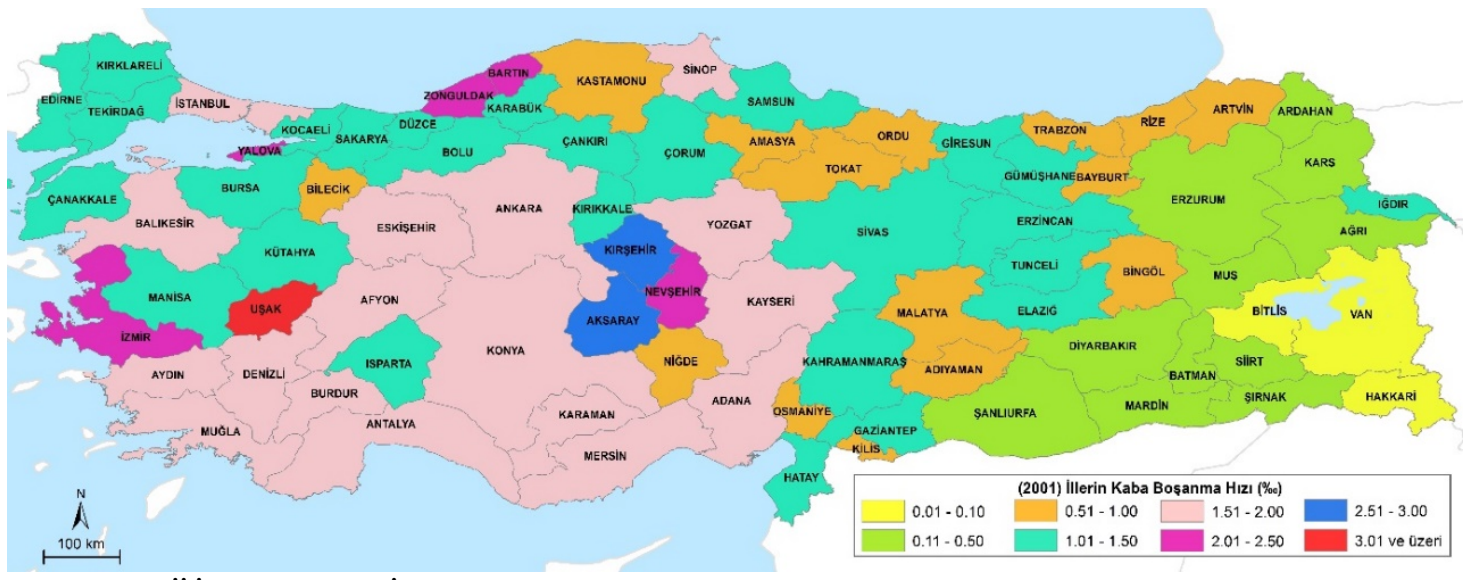

Kaynak: TÜİK Boşanma İstatistikleri (2001)

Harita 4. İllere Göre Boşanma Hızı (2016)

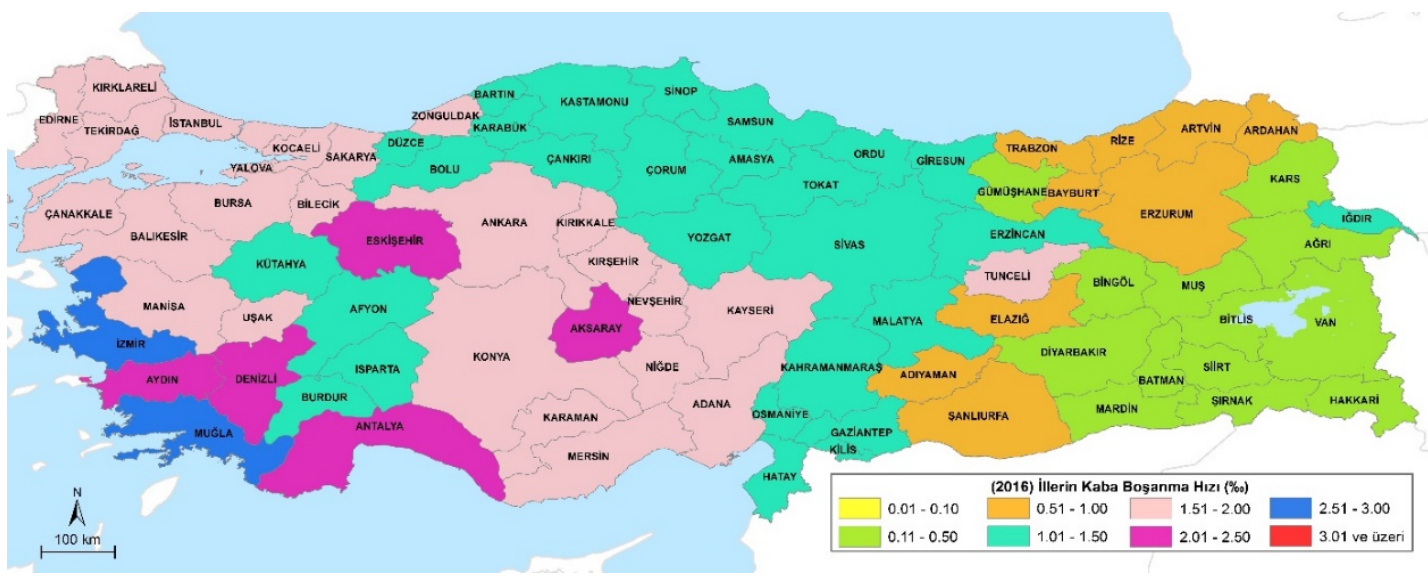

Kaynak: TÜİK Boşanma İstatistikleri (2016)

Van'da 2001-2006 yılları arasında boşanmalar en çok evliliğin 2. yılında; 2007-2011 yılları arasındaki evlilikler en çok evliliğin 3. yılında; 2012-2016 yılları arasındaki evlilikler ise en çok evliliğin 1. yılında gerçekleşmiştir. Evliliğin ilk yılının ardından çiftlerin beraber geçirdiği süre uzadıkça boşanma sayıları da buna ters orantılı olarak azalmaktadır. Van'da genel itibariyle evliliğin ilk 5 yılı ciddi risk oluştururken, 5. yılın ardından oranlar kademeli olarak azalmaktadır (Tablo 4).

Tablo 4. Van' da Evlilik Süresine Göre Boşanma Hızı

\begin{tabular}{|c|c|c|c|c|c|c|c|c|c|}
\hline & $\begin{array}{c}1 \text { Yildan } \\
\text { az }\end{array}$ & $1 \mathrm{Y}_{11}$ & $2 Y_{11}$ & $3 Y_{11}$ & $4 Y_{11}$ & $5 \mathrm{Y}_{11}$ & $\begin{array}{c}6-10 \\
Y_{11}\end{array}$ & $\begin{array}{c}11-15 \\
Y_{1}\end{array}$ & $16-+$ \\
\hline Van 2001-2006 & 7.000 & 9.66 & 11.66 & 11.33 & 10.33 & 9.000 & 27.66 & 17.000 & 22.33 \\
\hline Van 2007-2011 & 9.80 & 17.20 & 18.20 & 18.60 & 16.60 & 13.40 & 53.60 & 27.20 & 40.40 \\
\hline Van 2012-2016 & 10.80 & 38.20 & 28.60 & 28.40 & 21.00 & 19.80 & 70.20 & 32.40 & 49.6 \\
\hline
\end{tabular}

Kaynak: TÜİK Boşanma İstatistikleri (2001-2016) 
Van'da dikkat çeken diğer nokta ise boşanmaların kadın ve erkeklerde hangi yaş aralığında yoğunlaştığıdır (Tablo 5). Hem kadın hem de erkeklerde 16-19 yaş aralığındaki boşanma hızının 2001'den 2016'ya artarak devam etmesi Van' da erken yaşta evliliklerin her geçen yıl daha da arttığını göstermektedir. Çocuk gelinlerin çocuk damatlara göre daha yüksek orana sahip olduğu Van'da ayrıca erkeklerin boşanma oranı 30-34 yaş aralığında en yüksek seviyesine ulaşırken kadınların boşanma oranı ise 25-29 yaş aralığında en yüksek seviyeye gelmektedir. Hem kadınlar hem de erkekler, boşanma sayılarının en yüksek orana sahip olduğu yaşların ardından yaşları ilerledikçe her kademede neredeyse yarı yarıya düşmektedir.

Tablo 5. Van'da Kadın-Erkek Yaş Aralığına Göre Boşanma Hızı

\begin{tabular}{|c|c|c|c|c|c|c|c|c|}
\hline & & $16-19$ & $20-24$ & $25-29$ & $30-34$ & $35-39$ & $40-44$ & $45-49$ \\
\hline \multirow{2}{*}{$\begin{array}{r}\text { Van } \\
2001-2006\end{array}$} & Kadın & 2.66 & 23.50 & 29.0 & 24.16 & 14.33 & 9.5 & 6.0 \\
\hline & Erkek & 0.16 & 7.66 & 26.33 & 29.33 & 19.16 & 13.50 & 7.00 \\
\hline \multirow[t]{2}{*}{$\begin{array}{r}\text { Van } \\
2007-2011\end{array}$} & Kadın & 4.20 & 37.0 & 62.80 & 39.02 & 30.0 & 16.6 & 11.4 \\
\hline & Erkek & 0.20 & 10.40 & 44.40 & 52.80 & 42.0 & 30.6 & 15.4 \\
\hline \multirow[t]{3}{*}{$\begin{array}{r}\text { Van } \\
2012-2016\end{array}$} & Kadın & 7.0 & 60.8 & 78.0 & 64.6 & 36.80 & 21.0 & 12.2 \\
\hline & Erkek & 0.20 & 17.6 & 67.2 & 77.00 & 51.4 & 35.8 & 18.6 \\
\hline & & $50-54$ & $55-59$ & $60-64$ & $65-69$ & $70-74$ & $75-+$ & \\
\hline \multirow[t]{2}{*}{$\begin{array}{r}\text { Van } \\
2001-2006\end{array}$} & Kadın & 3.0 & 1.16 & 1.0 & 1.0 & 0.33 & 0.16 & \\
\hline & Erkek & 4.5 & 2.0 & 3.0 & 1.0 & 1.50 & 0.66 & \\
\hline \multirow{2}{*}{$\begin{array}{r}\text { Van } \\
2007-2011\end{array}$} & Kadin & 6.2 & 2.8 & 1.80 & 0.40 & 0.40 & 0.60 & \\
\hline & Erkek & 8.0 & 4.2 & 3.2 & 2.4 & 0.6 & 0.8 & \\
\hline \multirow[t]{2}{*}{$\begin{array}{r}\text { Van } \\
2012-2016\end{array}$} & Kadın & 9.0 & 3.8 & 2.80 & 1.60 & 0.40 & 0 & \\
\hline & Erkek & 12.2 & 10.0 & 3.4 & 2.20 & 1.8 & 1.4 & \\
\hline
\end{tabular}

\section{Aşiret Yapısında Boşanma Konusu}

Aşiretlerde evlilik kurgusu: Ailenin ilk kurulma aşaması olan evlilikler, boşanma süreçlerini anlama ve anlamlandırmada önemli evrelerden ilkini teşkil etmektedir. Boşanma ile neticelenen evliliklerin birçoğunda evlilik biçimi, aile ve akrabalık ilişkileri, tanışma süreci gibi yaşanan ilişkiler evlilikleri boşanmaya götüren sosyolojik zemini sunmaktadır. Van kent merkezinde aşiret üyesi boşanmış 10 kişi ile gerçekleştirilen görüşmelerde evlilik biçimi açısından görücü usulü ve severek evlilik türünde yoğunlaşma olduğu görülmektedir. Kişilerin severek evlilik olarak nitelendirdikleri türün irdelendiğinde buna ilişkin olarak Van'da farklı varyasyonların olduğu görülmektedir. Severek evliliklerin bünyesinde çocuk yaşta evlilik, akrabalık ilişkileri, kısa süreli birbirini tanıma ve aile baskısı gibi alt bileşenlerin hakim olduğu farklı bir türe evrildiği araştırma sonuçlarına yansımaktadır.

"Biz severek evlendik, uzaktan akrabayı. Üniversite şenliklerinde akraba vasıtasıyla tanıştık. Sonra aileler duydu, bir de baktık ki evlenmişiz. Evlenmeyi bile düşünmezken aileler kendi aralarmda düğ̈̈n, nişan, ev düzme işlerini bitirmiş bile" (K4) 


\begin{abstract}
“Akraba falan değiliz, aynı köylüyüz. Severek aldık birbirimizi. Gördük köy yerinde görüşmeye başladık. Yaşlarımız küçüktü ama onun ailesine laf gitmiş kızın filanla görüşüyor diye. Mecbur apar topar evlendik. Bizim aşirette ayıptır kızın namusuna laf getirilmez". (E1)

"Ben 12, eşim de 16 yaşında iken annemin isteğiyle evlendik. Teyzemin kızıydr. Annemin kızı olmadı̆̆ı için ev işlerinde yardımcı olması için aldık eski eşimi. Annem gördü, beğendi. İstemedim ama aileye karşı gelinmez bizim buralarda." (E4)
\end{abstract}

Nesiller arası kuşak çatışmalarının belki de en çok hissedildiği yerler olan geleneksel ve modernin çatıştığı Doğu illeri, bir yandan modern hayatı yakalamaya çalışırken bir yandan da yüzyıllardır geleneğin onlara dayattığı alışkanlıklarından kurtulamayan insanları temsil etmektedir. Dolayısıyla kadın ve erkek arasında görücü usulü ve severek evliliklerde yakın çevre, aile ve gelenek baskısı hakim olurken, hem görücü usulü hem de severek evliliklerin aynı tonda seyretmeyip form değiştirdiği görülmektedir. Özellikle katılımcıların severek evlilik olarak tanımladıkları evliliğin derinliklerine inildiğinde birbirlerini tanımaya fırsat vermeyen toplumsal normlarla karşı karşıya geldikleri dikkat çekmektedir. Aile, akraba ve sosyal çevrenin evliliğe teşvik edici baskılarının genç çiftler üzerinde bir baskı mekanizması oluşturduğu söylenebilir.

Boşanma davalarına bakan avukatlarla gerçekleştirilen görüşmelerde, Van kent merkezinde aşiret üyesi olup boşananlarda hem görücü usulü hem severek hem de berdelin en sık rastlanan evlilik türü olduğu ortaya çıkmaktadır.

\footnotetext{
"Yörenin etkisinden galiba, genelde bana başvuranlar görücü usulü evlenenler. Tabiki severek evlenenler de var, fakat gerçek aşk evliliği yok denecek kadar az". (KA1)

“Görücü usulü evlenen o kadar çok ki; özellikle de akraba evliliği. Dolayısıyla boşanan da. Müvekkillerime bakıyorum genelde amca çocukları, teyze-hala ya da kayınvalidenin kendi zevkine göre bulduğu gelinler". (KA3)
}

Boşanma avukatları ve aşiret üyesi boşanmış kişilerle gerçekleştirilen yarı yapılandırılmış görüşme çıktıları gösteriyor ki; Van kent merkezinde boşanma yaşanan görücü usulü ve severek evliliklerde gelenek, kültür, ataerkil yapı ve dini normların tartışılamaz, hoş görülemez olarak gördüğü boşanma olgusu geleneksel yapı içinde kırılmalar yaşarken, geleneğin baskıcı gücünün çözülmeye başladığı anlamı çıkmaktadır. Ayrıca modern dünyanın çıktılarından birisi olan severek evliliklerin toplumsal doku içinde artıyor olması, Van kent merkezinde geleneğin domine edici gücünün kırılmalar yaşadığını göstermektedir. Bir diğer görmezden gelinemeyecek nokta ise her iki evlilik türünde de aile ve toplumun etken bir aktör olarak evliliğe teşvik edici yaptırımlarının, çiftleri boşanmaya hazırlayan bir etken olarak karşımıza çıktığıdır.

Aşiretlerde evlilik sürecinde yönlendirme ailesinin rolü: İki kişi ile kurulacağ 1 düşünülen aile birlikteliğinin, yönlendirme ailelerinin de dahil olması ile alışıldık geniş aile formatından çıkması tam anlamıla sağlanamamıştır. Modernizmin gereklerinden olan bireysel özgürlük ve özerk olma arzusu ile ebeveynlerden ayrılıp bağımsız çekirdek aile kurma hevesinde olan bireyler, eşlerden biri ya da her ikisinin yönlendirme ailesi ile olan maddi ve manevi bağlılığı/bağımlılığı neticesinde çekirdek aile kuramamaktadır (Güleç, 1991, s. 265-368). Kültürel kodların güçlü olduğu geleneksel yapılarda sıkça görülen görücü usulü evliliklerde, kiminle, nasıl, ne zaman ve hangi şartlarda evleneceğine, ailede 
hiyerarşide en üstte bulunan bazen anne/baba bazen dede/nene bazen de amca/dayı ya da herhangi bir aile büyüğü kişi karar verir. Geleneksel toplumlarda sıkça rastlanan bir deyim olan 'eşinle değil, ailesi ile evleniyorsun' sözü de karı ve koca arasında kurulması gereken birliktelikte çiftlerin devre dışı bırakılarak yönlendirme ailelerinin kurduğu görülmektedir. Çeyiz adı altında çoğu zaman fikirleri dahi sorulmadan yeni evlenecek çiftin ev eşyaları, takacakları takı, kıyafetleri hazır olarak aileleri tarafından sunulmaktadır. Ailelerin söz sahibi olduğu bu süreçte, eğer aileler birbirleriyle anlaşıyorlarsa herhangi bir sorun yaşanmazken ailelerin anlaşamadığı durumlar gelin ve damadın da anlaşmazlık yaşamasına sebep olmaktadır. Gelin ve damada hazır olarak sunulan 'ismarlama hayatlar', ailelerin kurulduğu bu süreçte boşanmanın da nüvelendiği aşamalardan birisi olmaktadır.

Yönlendirme ailelerin evlilik örüntüsündeki yeri, boşanmaları anlamada önemli bir kriter oluşturmaktadır. Dolayısıyla geleneksel yapılarda boşanma ile sonuçlanan evliliklerde anne-baba, kayınvalide-kayınpeder ve dünür-hısım ilişkilerini analiz etmek bu manada önemlidir. Van kent merkezindeki boşanmış aşiret üyeleri ile gerçekleştirilen görüşmeler göstermiştir ki evlilik hazırlıklarında gelin ve damadın birbirleriyle değil de yönlendirme aileleri ile yaşadıkları çatışmalar ve yönlendirme ailelerinin birbirleri üzerinde kurmaya çalıştıkları tahakküm arzuları mutlu aile oluşumunu daha kurulmadan sekteye uğratmaktadır.

\footnotetext{
"Yani aileler istedi, bize kimse bişey sormadı. Evlenince de kayınvalide ve görümcelerimle ayn evde oturdum. Özel alanım sadece yatak odamdı, onu bile kendileri seçti, sormadılar gelin hanm sen hangisini istersin diye". (K1)
}

Görücü usulü ve akraba evliliklerinde aileler arasında herhangi bir sıkıntı yaşanmazken, her iki taraf da gelin ve damadın fikrinin alınmasına gerek olmadığı noktasında hemfikirlerdir. Aynı toplumsal yapı ve geleneklere hakim olan ilişkilerde çatışmalar yaşanmazken; kültür farklılıkları devreye girdiğinde hem yönlendirme aile üyeleri arasında hem de yönlendirme ailesi ve genç çift arasında sıkıntılar yaşanmaktadır. Geleneksel toplumlarda etkin olan görücü usulü ve akraba evliliklerinde yönlendirme ailelerinin evliliğe teşvik eden kararları, olası anne-baba, kayınvalide-kayınpeder çatışmalarını da bertaraf etmektedir. Kültürel kodların geçerli olduğu geleneksel yapı içinde, evliliklerde son karar mekanizması olan ailenin hiyerarşide en üst mertebesinde bulunan kişi, yeni kurulan gerek severek gerekse görücü usulü evlilikler üzerinde halen büyük bir etkiye sahiptir. Evliliklerde önemli bir aktör olarak bulunmayı kendisine görev edinen yönlendirme aile üyeleri, boşanan katılımcıların beyanlarına göre bilinçli ya da bilinçsiz boşanma konusunda önemli bir role sahiptirler.

Aşiret yapılarında boşanma nedenleri: Kadın ve erkeğin boşanma kararı almasına sebep olan anlık olayın ardında uzun soluklu bir arka plandan bahsetmek mümkündür. Dolayısıyla evlilik kararının alınmasından evliliğe hazırlık sürecine, ailelerin etkisinden kültürel, ekonomik ve sosyal farklılıklara kadar birçok etken evliliğin sonunu hazırlarken şiddet, aldatma ve ailelerin etkisi gibi nedenler asıl boşanma olayına gömülmüş etkenleri kamufle etmektedir. Çalışma kapsamında katılımcıların boşanma hikayelerinde satır aralarına yansıyan fiziksel şiddet, aldatma, kumar, erken yaşta evlilik, eve karşı ilgisizlik gibi etkenlerin boşanmada ön plana çıkan nedenleri oluşturduğu söylenebilir. Lakin sayılan birçok etkenin içinde dikkat çeken en baskın nedenin şiddet olduğu göze çarpmaktadır. Katılımcıların evlilikleri süresince çocuklarını korumak, aile kimliklerini kurtarmak, 
toplumsal baskıya maruz kalmamak adına ört bas edilen şiddet, boşanmaya sebep olan en büyük etken olarak dillendirilmektedir.

"Evliliğimin 3. günüydü, sebepsiz yere. Öyle dövdü beni. Daha küçüktüm, liseyi bitiren bir kız nasıl olur. Korkak, ürkek. Ne yapacağımı bilemedim. Aslında kayınvalide, kayınpeder, 2 bekar kaynım ve görümcemle beraber yaşıyorduk. Ağlayamadım bile. Korktum. Düşündüm, terk edip gitsem nereye giderim, kendi ailem zaten kıt kanaat geçiniyor. Aileme bile gitmeme izin vermezdi, 4 ayda bir, 1-2 saatliğine. Hatta bir keresinde bayramda gidip biraz fazla kaldık diye, eve gelince, arabanın kapısını kilitledi; saatlerce dövdü beni arabada (ağ̆ladl)." (K1)

Yapılan görüşmeler göstermiştir ki; kadınların şiddete bir yere kadar tahammül ettikleri; fakat söz konusu aldatma olduğunda hem kadın hem de erkeklerin beklemeksizin boşanmayı fiili anlamda gerçekleştirdikleridir. Tahammül edilemeyen, ertelenemeyen bir neden olarak aldatma, Van'da özellikle kumalık kültürünün hakim olduğu aşiret yapılarında 'erkektir ne yapsa yeridir' anlayışını kırmıştır. Sadakatin yalnızca kadınları ilgilendiren bir mevzu olmadığını erkeklerin de bu konuda sorumluluk sahibi olması gerektiğinin altını çizerek, artık kadının da evlilikte aktif konumuna geldiğini göstermektedir. 20-30 yıl öncesine kadar Van'da aşiret üyeleri arasında özellikle erkeğin aldatması noktasında boşanma nedeninden bahsedilemezken, bugün aşiret kadının aldatma sebebiyle boşanması modernleşen toplumsal yapıya işaret etmektedir. Kumalığın toplumsal kabul gördüğü durumdan, aldatma olarak nitelenen bir pozisyona gelmesi hizlı modernleşme hareketlerinden birisini göstermektedir. Aldatma konusunda dile getirilen hikayeler şu şekildedir:
“Evlendiğimin ertesi günü öğrendim birisi olduğunu, konuştum, ă̆ladım. Dövdü beni. Alışacaksın. Onu da alacam, beraber yaşayacaksınız dedi. Yikılmıştım. Evi terk etmekle tehdit ettim, 3 sene boyunca hiç ayrlmadı o kızdan. İkinci evlilik derdi hep, annesi de desteklerdi onu. Erkeğin hakkı derdi. Babasından destek bulamadığı için getiremedi eve, yoksa beni dinlediğinden değil" (K1)
"Eziyet görüyordum hep, bir de aldattığın öğrenince, dedim tamam bitti. Ailem kardeşlerim falan da eziyetlerini öğrenince öldürmek istediler. Sonra boşandım." (K2)

Görüşmelerden edinilen bilgiye göre diğer etkili boşanma sebebi de kayınvalide etkisidir. Kayınvalidenin genç çift üzerinde kurmaya çalıştığı otorite ve kızı ya da oğlunu kimseyle paylaşamama ve kıskanma dürtüsü olduğu sıklıkla dile getirilmektedir. Kayınvalidenin kendisine benzeyen bir kadın yetiştirme hayali ile genç kadının yeni kurduğu çekirdek ailesinde kendisini gerçekleştirme arzusunun çatışması sonucu ortaya çıkan tatsızlıkların birçoğu maalesef ki boşanma ile sonuçlanmaktadır. Van kent merkezinde geleneksel hayatların hüküm sürdüğü ailelerde kimi zaman kızın annesinin kimi zaman da erkeğin annesinin yeni kurulan aileyi kendi istekleri çerçevesinde oluşturma gayretleri aile içi ilişkileri sekteye uğratmaktadır.

"Eşim kayınvalidemle konuşurdu, içeri girer bana vurmaya başlardı. Kayınvalidem bize geldiğinde de hiç huzurumuz kalmazdl, sürekli beni şikâyet ederdi eşime, o da döverdi". (K1)

"Düşünsenize evlenmişsiniz, ilk gecenizde dahi kızını defalarca aradı. Sabah kahvaltı yaparken, yemek yerken, TV izlerken hep aradı. Baş başa yemeğe çısak -bak sen senin o 
beceriksiz kocan nereye götürdü seni? diye söylendi. Telefonlarımızı kapattık bir gün, çok bunaldım. Dedim eşime böyle olmaz. Beraber bir şeyler yapalım. Bu kez kendisi ulaşamayınca bize yakın oturan kız kardeşi vardl; onu eve gönderdi. Biz eşimin annesinden dolayı birbirimize alışamadı". (

Van'da boşanma davasına bakan avukatlar da görüşmelere paralel hikayeler anlatarak, en sık karşılaştıkları boşanma sebeplerini şu şekilde sıralamışlardır: Aile reisinin sorumluluklarını kumar, içki ve kaçakçılıktan dolayı yerine getirmemesi, kayınvalide etkisi ve şiddet. Avukat beyanlarına göre özellikle kayınvalide etkisi, geniş ailelerde neredeyse 3 kuşak birlikte yaşayan çiftlerin en büyük çıkmazlarından birisini oluşturmaktadır.

\begin{abstract}
"Kayınvalidesi yüzünden boşanan evli çift sayısı çok fazla. En azından benim davalarımda öyle. Gençlerin arasında bir sıkıntısı olmasa da erkeğin ya da kadının birbirlerine aile içinde sıcak davranamaması, zamanla iletişimsizliğe, birbirlerine karşı soğumaya sebep olmaktadır". (KA1)

"Şiddet ön sıralarda. Geniş aile olduğu için de kayınvalide çatışmaları da tabiki de etkili. Ama sınır iliyiz dolayısıyla madde bă̆ımlılığı ve kaçakçıllğı görmezden geliniyor. Sınır daha sıkı kontrol altında tutulursa birçok ailenin kurtulacağını düşünüyorum." (KA2)

"Şiddet, şiddet, şiddet. Her şeyin başı aslında bu. Yörenin de yapısı aslında buna çok olanak tanıyor. Maalesef kadın sessiz kalıyor, kalmak zorunda da aslında yapı onu gerektiriyor. Ama önce kadınlar şiddetten boşanamazdl, şimdi sayı giderek artıyor, uzaklaştırma kararı falan aldırmak hayaldi." (EA5)
\end{abstract}

Yönlendirme ailelerinin boşanmaya tepkisi: Boşanmanın düşünceye geldiği ilk andan gerçekleştiği ana kadar geçen süre boyunca çeşitli etkenleri göz önünde bulunduran çiftler çoğu zaman 'kaderine razı olarak' süreci akışına bırakmaktadırlar. Toplumun ve ailelerin baskısı sebebiyle çekirdek ailenin uzunca bir sürece yayılan boşanma kararı evresi, işin içine ailelerin tepkisi de girince iyice içinden çıkılmaz bir hal almaktadır. Toplumda yadırganacağı düşüncesiyle ailelerin çocuklarının boşanmasına karşı oluşturdukları ilk refleks duruma engel olmaya çalışmaktır. Evliliğin olgunlaşmaya başladığı ilk evreden itibaren aktör olan yönlendirme aileleri, söz konusu boşanma olduğunda da geleneksel yapının kendilerine verdiği görev ve sorumlulukla evliliği kurtarmak adına adımlar atmaktadırlar. Aşiret üyesi boşanmış 10 kişi ile Van kent merkezinde gerçekleştirilen görüşmeler neticesinde ailelerin boşanma söz konusu olduğundaki ilk tepkileri toplumsal baskının etkisiyle engel olmak ya da çözülen aileyi kurtaracak adımlar olurken ardından kangren olmuş ve kurtarılamayacak uzvu kesip atmaya ikna olmaktadırlar.

"Kendi annem eve gittiğimde benim ayakkabılarım uzun süre ayakkabılıkta sakladı, olur da düzelirse kimse bilmesin eve döndüğ̈̈mü diye. Biz uzun süre ailemin yanında olduğumu söylemedik. Ama akrabalık bir şekilde öğrendi herkes. Isşten eve gelince gizli gizli girerdim eve kimse görmesin, duymasın diye. Aslında annem öyle isterdi. Bizim ailede hiç boşanan yoktur, biz ilkiz ikimiz de. Artık düşünün ki en büyük dayım aldı yanına, düzelir diye bekledik kızım olmayacă̆ına biz de ikna olduk, karar senindir saygı duyariz dedi." (K4)

"Yaşımı başımı almışım, ne diyecekler bana. Onlar da yıllardır biliyor. İlk boşanmaya yeltendiğimde ama engel oldular, el alem ne der diye. Sana kim bakacak diye. Baktılar ki

SEFAD, 2020; (43): 345-368 
benim durum fena. Sesleri çıkmadı sonra ama duyurmamaya çalıştılar eşe dosta. Köye istemediler beni, TOKI'lerde ev tuttuk o yüzden."

"Benin annem hiç istemedi, teyzemin kızı ya. Ayıptır dedi, hatta köy yerinde sırt dönen çok akrabam oldu. Ama eşimin annesi destekliyordu. Görüyordu çünkü kızı da ben de mutsuzduk." (E4)

Boşanan kişilere yönelik toplumsal baskılar: Kadın ve erkeğin yaşamının yer aldığ toplumsal doku bazen açık bazen de dolaylı olarak evlilik ve boşanma süreçlerinde etken rol üstlenmektedir. Evlilik ve aileye dair oluşumlarda baskın karaktere sahip olan toplumsal çevre, söz konusu boşanma olduğunda sert bir kalkan oluşturarak, oluşacak olan vaziyete katı ve mesafeli bir tavır takınmaktadır. Ekonomik geçim koşulları, çocukların varlığı, çevreeş-dost-akraba-aile baskıları gibi konular sebebiyle uzunca bir sürece yayılan boşanma, sürecin gerçekleşmesinin ardından da birbirinden farklı tecrübeleri barındıran yeni hikayeleri oluşturmaktadır. Geleneksel toplum dokusuna sahip olan Van'da, özellikle aşiret üyesi bireylerin öncelediği toplumsal baskılar, yarı yapılandırılmış görüşme çıtılarından edinilen bilgiye göre hiç de yersiz değildir. Özellikle 'dul kadın' imajı ile toplumda boşanan kadın farklı bir statü ve sınıfta değerlendirilirken erkeğin ise sosyal çevrelerinde daha rahat bir ortama sahip oldukları görülmektedir.

\footnotetext{
"Hiç dışarı çıkmıyorum dedikodu olur diye. Çıkarsam da yanıma ya annemi ya da babamı alıp çocukları gezdirip getiriyorum. Dulsun ya hani, ne bileyim. Camdan bile bakmaya çekiniyorum aslında. Ben işim olup dışarı çıktı̆̆ımda komşuların falan arkamdan baktığın görüyorum. Çekiniyorum. Bir de o iftirayı kaldıramam. Maddi imkanlarım olsa bile zaten ailem de ayru bir eve çımama izin vermez. Annem hep der başında koca olmayan kadın tek başına yaşayamaz diye." (K1)

"Babam bana ayrı ev açtı boşanınca kızımla beraber. Ben nasıl neşeli, güler yüzlü bir kızdım. Gülersem yanlış anlaşılır diye sert mizaçlı, asık suratlı biri gibi davranıyorum apartmanda. Kimse bir şey demesin diye. Dul kadın olmak zor, sanki bizim artık bişey yapmaya, gülmeye hakkımız yok. Mesela saçımı boyatmak istiyorum yollu diyecekler diye yapamıyorum". (K3)
}

Geleneksel, ataerkil yapının hakim olduğu toplumlarda kadın, korunup kollanması ve kamusal alanda baskı ile sınırlandırılması gerektiği öngörülmekle birlikte (Walby, 1991); evlenmeden önce babası ya da erkek kardeşi, evlendikten sonra kocası, boşanma sonrasında da tüm toplumsal çevrenin himayesine hapsedilmektedir. Boşanma sonrası kadının namusunun korunma olgusunun topluma devredilmesi ya da toplumun kendisini bu noktada sorumlu hissetmesi, namus kavramını sadece kadınlar için gerekli kılmaktadır. Boşanma sonrası 'el alem ne der' korkusu kadının ataerkil kabusunu açığa çıkarmakla birlikte; sonrasında Kandiyoti'nin (1988) deyimiyle 'ataerkil bir pazarlı' içine girerek kendisini topluma 'dul kadın' olarak kanitlamaktadır.

Boşanma sonrası kadınlar için bir problematik oluşturan dulluk imajı erkekleri herhangi bir sosyal sınıfa oturtmamaktadır. Boşanma sonrası en az hasar alan erkekler olurken; toplumsal kontrol mekanizmaları kadını kıskaç içine alarak denetleme görevini kendilerine sorumluluk edinirler. Kadına en büyük zararın hemcinsleri aracılığıyla geldiği gerçeğiyle, ataerkil toplum yapısında kadının konumlandırıldı̆̆ı durum toplumda meşrulaştııılmaktadır. Toplum tarafından denetime tabi tutulan kadın, hemcinsleri tarafından kimi zaman meraklı, sorgulayan ve hesap soran bakışlarla kimi zaman da 
iletişimsizlikle cezalandırılmaktadır. Toplumsal kontrol mekanizmasının bizzat üreticisi olan erkek ise 'namus' adı altında denetlenmezken, boşanan kadın; 'namussuz' ya da 'düşük ahlaklı', 'ahlaksız davranışta bulunma potansiyeli olan' olarak değerlendirilmektedir. Sosyalizasyon süreci boyunca erkeklere dikte edilen kadının koruyanı, evin ekmek getireni, namus bekçisi, güvenliği sağlayan kişi imajı sebebiyle, kadın bu zincirden kurtulur kurtulmaz korunaksız kaldığı/kalacağı beklentisini oluşturmaktadır. Toplumsal cinsiyet kapsamında erkeğe yüklenen bu görevler zamanla toplumda kadının kendisi tarafından bile kabul görmekte ve kadını kocası olmayan bir hayat düşüncesi dahi korkutmaktadır. Gündelik yaşam pratiklerinde hala geleneksel dokunun etkisinde kalan Van kent merkezinde, modern ve hatta postmodern dönem tecrübe edilirken aşiret gerçekliğinin etkisiyle eski alışkanlıklarını devam ettirmektedir. Örf-adetler, kültürel alışkanlıklar çerçevesinde gündelik hayatı idame ettiren Van'da, tam adıyla günümüzde adına aşiret denemese de yüzyıllardır geleneksel yapının hâkim olduğu dokunun dönüşmesi Batı kadar mümkün görünmemektedir. Alışkanlıkların hâkim olduğu toplumsal dokuda, erkek tahakkümünde erkek egemen söylemlerin ve pratiklerin halen geçerliliğini koruduğu görülmektedir.

\section{SONUÇ}

Geleneksel sosyolojik dokunun baskın olduğu bir kent özelliği gösteren Van'da 20012016 yılları arasında \%319 oranında artan boşanma olaylarını odağına alan bu çalışmanın ortaya koyduğu çıkarımları ana hatlarıyla şu şekilde ifade etmek mümkündür:

- Van'da boşanmalar en fazla kadın ve erkek 25-29 yaş aralığında ve evliliğin 2. ve 3. yıllarında gerçekleşirken 5. yılın ardından ise kademeli olarak azalmaktadır. Ayrıca 2001'den 2016'ya dek 16-19 yaş aralığında artan boşanma oranları, aşiret yapılarının baskın olduğu Van'da erken yaşta evliliklerin Türkiye ortalamasının aksine artarak devam ettiğini göstermektedir.

- Ailenin ilk kuruluş aşaması olan evlilikler Van'da eklektik bir düzlemde yaşanmaktadır. Aşiret mensupları arasında severek ve görücü usulü evliliklerin form değiştirdiği dikkat çekmektedir. Dolayısıyla tam manasıyla ne görücü usulü ne de severek evlilik denilebilecek evlilikler Van'da aşiretlerin modernleşen yüzünü gözler önüne sermektedir.

- Özellikle aşiret toplumlarında mahrem olan aile ilişkilerinin kamusal bir boyut kazanarak 'el alem ne der' kaygisı ile 'kolun kırılıp yenin içinde kaldığı' dönem yerini 'benim hayatım benim kararım'a bırakmıştır. Toplumsal kontrol mekanizmaları tarafından 'namus' ile terbiye edilmeye çalışılan kadının, erkeğin himayesinde kalmaya zorlandığı 'gelinlikle girer kefenle çıkarsın' mottosu, Van'da aşiret üyelerince tabu olarak muamele gören boşanmanın, artık gündelik pratikler içinde değerlendirilmeye başlandığı görülmektedir.

Aşiret yapılarında baskın bir zemine oturan aile büyüklerine koşulsuz itaat ve buna bağlı olarak aile büyüklerinin aile içindeki otoriter rolü bugün halen etkisini gösterirken, yeni nesille beraber kolektif bir tarza sahip olan aile ilişkilerinin bireyselleştiği görülmektedir.

SEFAD, 2020; (43): 345-368 


\section{SUMMARY}

In recent years, increasing divorce rates followed by a decrease in marital fertility rates force societies to revise the family institution around the globe. Divorce is defined as a court decision that terminates the emotional and physical coexistence of man and woman who have been married legally. Divorce transforms societies with its effects in social, cultural, religious, economic and psychological dimensions. Since marriage and divorce cases reflect the sociological characteristics of their geography, social structure should be studied to better understand the divorce pattern of a particular location.

As one of the traditional family structures, tribal formations consist of patriarchal extended families living collectively as a closed small society. In tribal formations, the sole and ultimate decision maker is the eldest member of the family who values the well-being of the family strictly above individual needs/wants of the family members. These tribal formations, which is widely prevalent among Kurdish population living in Van, put on display a social model where women are considered subordinate and oppressed by men. Since tribal connections are mostly maintained through marriages, the marriage process itself encapsulates the ideology, hierarchy, rules and relationships of the tribes. Common marriages types like marriage between cousins, 'berdel' (two men marrying each other's sisters), and child marriage provide more control of the tribe through family connection. Among these, child marriage and polygamous marriage signifies prestige within the tribe since it shows the economic and political power of the tribe member.

The main focus of the research is to examine which social factors are behind the $319 \%$ increase in the divorce rates between the years of 2001-2016 in Van, where traditional values are dominant due to the province's tribe-based social structure. Specifically, attitudes and norms of the divorced tribe members towards marriage, family, and divorce need to be elicited to infer these factors that are thought to be linked closely to the tribal structure of the province. To this end, qualitative and quantitative research methods have been employed. Quantitative data were obtained from TUIK records, and qualitative data were obtained from interviews carried out with five male and female divorced tribal members along with five divorce lawyers in the city center of Van. Semi-structured interviews with a total of 15 people in the city center of Van were conducted in places such as houses, cafes, and workplaces where the participants felt comfortable. The interviews were recorded with a tape recorder and then transcribed verbatim. Raw secondary data obtained from TUIK was analyzed by Duncan Multiple Range Test according to three different year categories as 2001-2006, 2007-2011 and 2012-2016. The analyses of the differences between years and variables led to significant differences $(p<0.01)$. In the mapping part of the study, the Geographical Information Systems (GIS) was used to read the numerical data obtained from TUIK.

According to the official records, the number of divorced people in Van increased from 78 in 2001 to 327 in 2016, which corresponds to a 319\% increase for the respective period. Also, the continuously increasing number of divorced women and men aged between 16-19 shows that marriages at an early age have increased each year between 2001 and 2016 as well. In Van, where child brides have a higher rate than child grooms, the divorce rate of men reaches the highest level between the ages of 30-34 and the divorce rate of women reaches its highest level between the ages of 25-29. 
Although divorce has been considered as an indisputably wrong action within tribal formations due to traditional, religious, and patriarchal norms, inferences from the semistructured interviews show that attitudes toward the divorce phenomenon has now started to be changed in Van.

In tribal formations, the person who occupies the decision making position within the family hierarchy carries a considerable power over marriages of the family members whether it is a love marriage or an arranged one. The elderly who constantly interfere with the marriage life of couples (whether on purpose or not) are one of the main reasons behind the divorce cases, according to the statements of the divorced interviewees.

Qualitative and quantitative data reveals that one of the main causes of divorce cases in Van is husband's cheating on wife. This proves that the patriarchal idea of "whatever man does is right" has started to be challenged by women living in tribal families. The interviews show that women tolerate spousal violence and/or domestic violence to a certain extent but they take legal action for divorce immediately when it comes to cheating. The second main reason behind divorce cases in Van is that mother of the married woman or man sometimes disrupts the family order in various forms in order to shape the newly formed family according to her own desires, beliefs, and norms.

The semi-structured interviews demonstrate that the social pressure rooted in tribal formations carries great importance in understanding marriage and divorce phenomena in Van. While a divorced woman is labeled as "widowed woman" and assigned a lower status within tribal formations and in the society as a whole, a divorced man has a more comfortable and freer space to live in this social environment. The family matters that once were very private and confidential especially in tribal societies have now been made publicized. The belief "whatever happens in the family stays within the family" has been replaced by voices of "my life, my decision".

All in all, it is seen that divorce, which has remained as a taboo for tribe members living in Van, is now considered as a normal stage within the flow of life. In turn, this shift in marriage norms has begun challenging and transforming the tribe formations dominated by patriarchal values which caused unfair treatment of women under the patronage of men. 


\section{KAYNAKÇA}

Albers, C. M. \& Newman, D. (1999). Sociology of families. London: Pine Forge Press.

Baudrillard, J. (2003). Simülarklar ve simülasyon. (O. Adanır, çev.). Ankara: Doğu-Batı Yayınları.

Bauman, Z. (2001). Parçalanmış hayat- postmodern ahlak denemeleri. (İ. Türkmen, çev.). İstanbul: Ayrıntı Yayınları.

Bauman, Z. (2009). Akışkan aşk- insan ilişkilerinde kırılganlı̆̆a dair. (I. Ergüden, çev.). İstanbul: Versus Yayınları.

Bauman, Z. (2017). Yaşama sanatı. (A. San, çev.). İstanbul: Ayrıntı Yayınları.

Beck, U. \& Beck E. (2012). Aşkın normal kaosu. (N. Ermiş, çev.). İstanbul: İmge Yayınevi.

Becker, H. (1981). A treatise on the family. Cambridge, MA: Harvard University Press.

Beşikçi, İ. (1992). Doğu'da değişim ve yapısal sorunlar: göçebe Alikan aşireti. Ankara: Yurt Yayınları.

Bruinessen, M. V. (2015). A $\breve{g} a$, şeyh, devlet. (B. Yalkut, çev.). İstanbul: İletişim Yayınları.

Can, İ. (2014). Moderniteden postmoderniteye ailenin ontolojisi ya da modern çekirdek aile çerezleşiyor mu? M. Aydın (Ed.), Aile sosyolojisi içinde (s. 51-81). İstanbul: Açılım Kitap.

Canatan, K. (2016). Ailenin tanımı, türleri ve işlevleri. K. Canatan- E. Yıldırım (Ed.). Aile sosyolojisi içinde (53-64). İstanbul: Açılım Kitabevi.

Cheal, D. (1999). The one and the many: modernity and postmodernity. G. Allan (Ed.). The sociology and the family içinde (s. 56-85). Oxford: Blackwell.

Cherlin, A. J. (1992). Marriage, divorce, remarriage. Cambridge: Harvard University Press.

Cohen, T. F. (2005). The meaning of marriage and the family. B. Strong- C. DeVault- T.F. Cohen (Ed.) içinde The marriage and family experience (s. 180-193). USA: Thomson.

Coleman, J. (1988, Jul). Social capital in the creation of human capital. American journal of sociology. 94, 95-120, http://www.jstor.org/stable/2780243?origin=JSTOR-pdf. Erişim tarihi: 19.12.2019.

Çiçekli, A. (2019). Boşanmalar üzerine sosyolojik bir araştırma: Van örneği (2001-2016). (Yayımlanmamış doktora tezi). Van Yüzüncü Yıl Üniversitesi, Van.

DİE (Devlet İstatistik Enstitüsü). (2000). Genel nüfus sayımı nüfusun sosyal ve ekonomik nitelikleri. 65-Van İli. Ankara: DİE Matbaası.

Dikeçligil, B. (1995). Türk toplumunda aile tipleri. Cumhuriyet dönemi Türkiye ansiklopedisi. (C. 11, s. 16-226). İstanbul: İletişim Yayınları.

Eyce, B. (2002). Demografik özelliklere göre Türkiye'de boşanma. SDÜ Fen-Edebiyat Fakültesi/Edebiyat Dergisi, 14, 81-98. http://sefad.selcuk.edu.tr/sefad/article/view/557/533. Erişim tarihi: 10.12.2019.

Fuchs, V. R. (1983). How we live. Cambridge, MA: Harvard University Press.

Furstenberg, F. F. \& Kiernan, K. E. (2001). Delayed parental divorce: how much do children benefit?. Journal of marriage and family, 63, 446-457. doi: 10.1111/j.1741-3737.2001.00446.x

Furstenberg, F. F. (1998). Social capital and the role of fathers in the family. A. Booth -N. Crouter (Ed.). içinde Men in families: When do they get involved? What difference does it make? (s. 295-301). Mahwah, NJ: Erlbaum.

Giddens, A. (2000). Sosyoloji. (H. Özel- C. Güzel, çev.). Ankara: Ayraç Yayınları. 
Giddens, A. (2014a). Modernliğin sonuçları (6.bs.). İstanbul: Ayrıntı Yayınları.

Giddens, A. (2014b). Mahremiyetin dönüşümü (3.bs.). İstanbul: Ayrıntı Yayınları.

Gökçe, B. (1996). Türkiye'nin toplumsal yapısı ve toplumsal kurumlar. Ankara: Savaş Yayınları.

Kandiyoti, D. (1987). Emancipated but unliberated? reflections on the turkish case. Feminist studies, 13 (2), 317-338. Erişim adresi: http://www.jstor.org/stable/3177804

Kimmel, M. (2002). The birth of the self-made man. R. Adams- D. Savran (Ed.) The masculinity studies reader içinde (s. 98-122). Oxford: Blackwell.

Kümbetoğlu, B. (1997, Yaz). Aile, evlilik, nikah: farklılaşan kavramlar. Toplum ve bilim, 73, 129-145.

Laslett, B. (1972). Household and family in past time. London: Cambridge University Press.

Newman, D. M. (1999). Sociology of families. London: Pine Forge Press.

Özer, A. (1993). GAP ve sosyal değişme. Ankara: GAP Araştırma ve Uygulama Yayınları.

Özer, A. (2003). Doğu'da aşiret düzeni ve Brukanlar. Ankara: Elips Kitap.

Öztürk, M. (2004). 16. yüzyılda Kilis Urfa Adıyaman ve çevresinde cemaatler-oymaklar. Elâzı̆̆: Fırat Üniversitesi Orta Doğu Araştırmaları Merkezi Yayınları.

Parin, S. \& Demirci, E. Y. (2016). Sosyo-ekonomik göstergelerle Van (1963-2013). S. Parin (Ed.). Van kent araştırmaları içinde (s. 11-39). İstanbul: Bağlam Yayınları.

Parin, S. (2018). Aşiret ve ă̆alı̆̆ın kent formları üzerine bir araştırma: Van kent merkezi örneği. (Rapor No. SBA-2018-6994) Van: Van Yüzüncü Y1l Üniversitesi Bilimsel Araştırmalar Proje Müdürlüğü.

Poole, M. (2005). Changing families, changing times. M. Poole (Ed.). Family: changing families, changing times içinde (s. 1-19). Sydney: Allen \& Unwin.

Poster, M. (1978). Critical theory of the family. London: Pluton.

Riessman, C. K. (1990). Divorce talk, women and men make sense of personal relationships. London: Rutgers University Press.

Ritzer, G. (2000). Büyüsü bozulmuş dünyayı büyülemek. (S. Kaya, çev.). İstanbul: Ayrıntı Yayınları.

Sancar, S. (2013). Erkeklik: Imkânsız iktidar-ailede piyasada ve sokakta erkekler. İstanbul. Metis Yayınları.

Sevim, Y. \& Güldeste, A. \& Öner, C. (2016). Boşanan erkeklerin sorunları üzerine sosyolojik bir araştırma (Elâzı ̆̆ İli Örneği). Fırat Üniversitesi Sosyal Bilimler Dergisi, 2 (26), 293-312. doi: 10.18069/firatsbed.346938.

Stacey, J. (1996). In the name of the family: rethinking family values in the postmodern age. Boston: Beacon Press.

Stirling, P. (1965). Turkish village. New York: John Wiley and Sons.

Stone, L. (1979). The family, sex and the marriage in England 1500-1800. New York: Harper \& Row.

Stone, L. (1989, March). The road to polygamy. New York review boks, 36 (3), 51-75.

Türkdoğan, O. (2013). Günümüz Türk toplumunda doğu-güney doğu ve kabile-aşiret yapısı. Konya: Çizgi Kitabevi. 
Uluç, A. V. \& Karasu M. A. (2015). Kente yerleşmiş aşiret üyelerinin kentlileşme eğilimleri üzerine bir çalışma: Şanlıurfa örneği. Yönetim Bilimleri Dergisi, 13 (25), 201-232. Erişim adresi: https://dergipark.org.tr/tr/download/issue-file/18395

Walby, S. (1991). Theorizing patriarchy. Oxford: Blackwell.

Walzack, Y. \& Burns, S. (2004). Boşanma ve çocuk üzerine etkileri. (İ. Ersevim, çev.). İstanbul: Özgür Yayınları.

Yalçın-Heckmann, L. (2016). Kürtlerde aşiret ve akrabalık ilişkileri. İstanbul: İletişim Yayınları.

Yıldırım, A. (2004). İki aşiret arasında kültürel rekabet ve çatışma. (Yayımlanmamış yüksek lisans tezi). Hacettepe Üniversitesi, Ankara.

Yıldırım, E. (2016). Aile ve evlilik türleri. K. Canatan- E. Yıldırım (Ed.). Aile sosyolojisi içinde (s. 65- 82). İstanbul: Açılım Kitabevi.

Yıldız, M. Z. \& Alaeddinoğlu, F. (2016). Göç ve yoksulluk: Van kenti örneği. S. Parin (Ed.). Van kent araştırmaları içinde (s. 213 -258). İstanbul: Bağlam Yayıncılık.

Zaretsky, E. (1976). Capitalism, the family and personal Life. New York: Harper \& Row. 